\title{
Morpho physiographic characterization of the Samambaia creek's watershed, Goiânia-GO
}

\section{Caracterização morfofisiográfica da bacia hidrográfica do Córrego Samambaia, Goiânia-GO}

\section{Diogo Silva PENA ${ }^{1}$; Fernando Rezende da COSTA2; Derblai CASAROLI ${ }^{3}$; Adão Wagner Pêgo EVANGELISTA ${ }^{4}$; Luciele Vaz da SILVA ${ }^{5}$}

\author{
${ }^{1}$ Mestre em Agronomia; Universidade Federal de Goiás;diogospena@hotmail.com \\ 2 Mestre em Agronomia; Universidade Federal de Goiás; fernandocosta@hotmail.com \\ ${ }^{3}$ Prof. Dr. em Agronomia; Universidade Federal de Goiás; derblai.ufg@gmail.com \\ ${ }^{4}$ Prof. Dr.,em Agronomia; Universidade Federal de Goiás; awpego@bol.com.br \\ ${ }^{5}$ Autor para correspondência: Mestranda em Agronomia; Universidade Federal de Goiás; Endereço: Departamento de \\ Biossistemas, Escola de Agronomia /UFG - Campus Samambaia - Rodovia Goiânia/ Nova Veneza, km 0, Cep: \\ 74690900 - Goiânia, GO - Brasil, Telefone: (62) 35211557; lucieletga@gmail.com
}

Recebido em: 18-10-2014; Aceito em: 02-02-2015

\begin{abstract}
Delimitation of watersheds and its morpho physiographic features are common practices used in hydrologic and environmental analysis. The aim of this paper was to analyze the Samambaia's watershed and determine its morpho physiographic characteristics and track modifications made on land use throughout the years. Altimetry data was provided by SRTM radar program, compiled in a GIS created to store, process and analyze all the available data. A digital elevation model (DEM) was created from the SRTM image and used to delimitate the watershed. Final analysis of the morpho physiographic characteristics showed that Samambaia's watershed has a low propitious for floods. The region also showed intensification of urban areas when considering the last 25 years $(\approx 20 \%)$.
\end{abstract}

Additional keywords: morphometric; physiographic; use and occupation.

\section{Resumo}

A delimitação de uma bacia hidrográfica e sua caracterização morfofisiográfica são procedimentos comumente utilizados em análises hidrológicas e ambientais. $O$ objetivo deste estudo foi determinar as características morfofisiográficas e as alterações no uso e no manejo do solo da bacia do córrego Samambaia, nos últimos 25 anos. As informações de altimetria da região foram extraídas de imagens SRTM, utilizando um software de processamento de dados e SIG, gerando um modelo digital do terreno, utilizado para a delimitação semiautomática da bacia hidrográfica. A análise destas informações determinou que a bacia do Córrego Samambaia possui características que mostram baixa propensão a cheias e inundações, apresentando também uma intensa urbanização ao longo dos últimos 25 anos ( $20 \%)$.

Palavras-chave adicionais: fisiografia; morfometria; uso e ocupação.

\section{Introduction}

Currently, the watershed is a major territorial management unit that we have available to agroforestry activities, being shaped by geological and climatic conditions of the location. However, due to the development of society, watersheds have increasingly suffered canal physical structure changes, the composition of the biota, the hydraulic system and the flow of matter and energy (Lucas et al., 2010). These changes, combined to spatial patterns of use and land cover, have important effects on the production and transport of sediments (Vanacker et al., 2005).

The hydrography of a watershed reflects geological structure, regional morphogenetic evolution, climate and human interventions, and land use is the main human activity affecting the water regime of a watershed. However, other activities such as the implementation of drainage networks may also cause considerable changes (Latrubesse et al., 2005).

The morphometric characterization of a watershed is one of the first and most common procedures performed in hydrological or environmental analysis. It aims to clarify issues related to the understanding of local environmental and regional dynamics. Thus, the knowledge of natural conditions of this unit may ensure a greater efficiency of interventions that may be performed (Carelli \& Lopes, 2011).

The extraction of morpho physiographic features from digital terrain models (DTM) generated by satellite data has received considerable attention, being recognized as a viable alternative to traditional treatments and to manual evaluation of topographic maps, since computational procedures reduce the time required for the generation of information plans 
for analysis of hydrological models (Colombo et al., 2007).

The objective of this work was to perform the morphometric and physiographic characterization of the Samambaia creek's watershed from a geographical information system (GIS).

\section{Material and methods}

The study area is located in the north of the city of Goiânia, state of Goiás, Brazil Midwest, having as UTM coordinates $682,906 \mathrm{~m} \mathrm{E}$ and 8,163,272 $\mathrm{m} \mathrm{S}$ (zone 22) at the mouth with the Meia Ponte River, and UTM 689,413 $\mathrm{m} \mathrm{E}$ and 8,171,711 $\mathrm{m} \mathrm{S}$ (zone 22) in the region further north. The Samambaia creek is a tributary of the Meia Ponte River. Its watershed covers an area of $34.63 \mathrm{~km}^{2}$, representing $4.6 \%$ of the total municipal area, which has $739.49 \mathrm{~km}^{2}$ (IBGE, 2011), and having a main course of water with a length of $12 \mathrm{~km}$.

From slope, drainage networks and field observations maps, such as expeditious topographical surveying, recognition of vegetation types and vegetation patterns, which helped in understanding the existing soil type, a soil map was generated, correlating slope classes to soil classes updated by EMBRAPA (2006).

The watershed divider of the Samambaia creek area was generated from three-dimensional images of the Shuttle Radar Topography Mission (SRTM), with a spatial resolution of $90 \mathrm{~m}$.

The SRTM images used to obtain altimetric information in the region were extracted from the software ArcGis 9.3, which includes the creation of a database in a Geographic Information System (GIS) and generating a digital terrain model (DTM), which allowed to perform a semi-automatic delineation of the watershed.

After defining the area and the perimeter of the watershed, it was possible to obtain different morpho physiographical characteristics such as: (i) coefficient of compactness: expresses the relation between the perimeter of the watershed and a circumference of a circle with an area equal to that of the watershed (Cardoso et al., 2006). This is given by the equation (1) (Villela \& Matos, 1975):

$\mathrm{K}_{\mathrm{C}}=0.28\left(\frac{\mathrm{P}}{\sqrt{\mathrm{A}}}\right)$

where $K_{c}$ is the compactness coefficient (dimensionless); $\mathrm{P}$ the perimeter $(\mathrm{km})$; and $\mathrm{A}$ the watershed area $\left(\mathrm{km}^{2}\right)$; (ii) Form factor: relates the shape of the watershed with a rectangle (Teodoro et al., 2007). It was obtained by the following equation (2) (Villela \& Matos, 1975):

$\mathrm{F}=\left(\frac{\mathrm{A}}{\mathrm{L}^{2}}\right)$

where: $F$ is the form factor (dimensionless) and $L$ is the axial length of the axis of the watershed $(\mathrm{km})$; (iii) Circularity index: this index shows to what extent the shape of the watershed becomes a circle, according to equation (3) (Cardoso et al., 2006):

$\mathrm{IC}=\frac{12.57 \mathrm{~A}}{\mathrm{P}^{2}}$

where: $I C$ is the circularity index (dimensionless), and $P$ the perimeter (km); (iv) Slope and altimetric amplitude: this has an influence on the occurrence rate of runoff, which in turn affects the time rainwater takes to concentrate on riverbeds (time of concentration), which forms the drainage network of the watershed. Flood peaks, infiltration and soil erosion susceptibility depend on the speed with which the flow of rainwater occurs on the land of the watershed (Villela \& Matos, 1975; Antoneli \& Thomaz, 2007). The altitude variation is associated with precipitation, evaporation and transpiration, and consequently it has an influence on the average runoff. Large variations in altitude in a watershed cause significant differences in average temperature, which may give rise to variations in evapotranspiration (Lima et al., 2001); (v) Order: the order of watercourses was determined following the criteria established by Strahler (1957), in which no tributary canals are characterized as first order. Second-order canals are those stemming from the confluence of two first-order canals and may have tributaries of the first order. Third-order canals originate from the confluence of two second-order canals and may receive tributaries from the second order, first order, and so on. The addition of a given canal order to a higher-order canal does not change its order; (vi) Drainage density: formed by the main river and its tributaries (no official name), being determined by equation. (4):

$D_{d}=\left(\frac{L t}{A d}\right)$

where: $D_{d}$ is drainage density $\left(\mathrm{km} \mathrm{km}^{-2}\right)$; Lt, the total length of rivers or canals $(\mathrm{km})$; and Ad the drainage area $\left(\mathrm{km}^{2}\right)$; (vii) Sinuosity: the Sinuosity Index $\left(\mathrm{S}_{\mathrm{i}}\right)$ relates the true canal length (orthogonal projection) to vector distance (straight length) between two end points of the main canal (equation (5)):

$\mathrm{S}_{\mathrm{i}}=\left(\frac{\mathrm{Lp}}{\mathrm{DV}}\right)$

where: Lp is the length of the main canal $(\mathrm{km})$ and Dv the vector distance $(\mathrm{km})$.

The determination of classes of soil use was obtained from remote sensing techniques (Carvalho et al., 2008). Thus, the Vegetation Index by Normalized Difference (VIND) was applied to studies of vegetation dynamics and determination of different types of vegetation using images from sensors TM and ETM+ from the Landsat satellite and from the CCD sensor from Cbers satellite. Land use classes of Samambaia creek watershed were determined in two 
different periods, performing an analysis of vegetation dynamics, assessing where there was suppression and where vegetation sprung up. It is worth mentioning that due to the spatial resolution of the sensor and the scale of mapping, some small fragments may not have been mapped. Therefore, an accuracy of $900 \mathrm{~m}^{2}$ was defined, which corresponds to a pixel size. All processing and treatment of the images was performed with the software ENVI 4.3, and the assembly of the layouts and the generation of thematic maps were made with the software ArcGIS 9.3 (ESRI, 2008).

Both images used in the study are from the Landsat 5 TM satellite, one dated 08/16/2011 and the other 06/05/1986. Both were georeferenced based on a Geocover image from the GLCF/NASA program (Landsat 5 TM). Ten control points within the area of interest were located.

An unsupervised classification was made using IsoData data method, generating seven thematic classes that were subsequently reclassified into three classes. The end products of this process were two thematic maps of soil use and occupation. The maps generated regarding soil use and occupation were analyzed by comparing the quantitative values for each class of use that occurred during the 25 years analyzed.

Still, there was a historical survey of the vegetation using the interpretation of satellite images, which corresponded to the scene 222_71, from the Landsat 5 TM satellite, of 06/05/1986, where through a supervised classification these vegetation types were correlated to other existing at nearby locations. Validation of this routine was made from field visits, performing an in loco classification of the remaining fragments of vegetation, being then correlated to the data and the analysis from the interpretation of the image.

\section{Results and discussion}

The distribution of soil classes denotes a predominance of Latosols (dystrophic dark - Led2), with a texture from medium to clay, in approximately $65.18 \%$ of area. Pissarra et al. (2004) state that Latosols are able to be used for both agriculture and urbanization. In the case of the growing urbanization, increasing waterproofing elevates the risks of flooding and/or floods.

On the other hand, the class of Argisols (Eutrophic Red - Pve), with the second largest quantity with about $26.69 \%$ of the area, is associated to more sloped and strongly wavy reliefs, for a greater variability of physical properties of the soil also results in greater variability in the soil's water holding capacity. Still, serious problems of erosion are observed in those soils where there is a great textural difference between $A$ and $B$ horizons, as is the typical case of argisols, which feature a Bt horizon, being the problem greater as soil sloping increases. According to Sordi et al. (2012), Argisols have as a main characteristic increased clay in surface horizon $A$ towards subsurface horizon $B$, which is of a textural type $(\mathrm{Bt})$, usually accompanied also by a good distinction of color and other characteristics. It is characterized by a large vertical migration, which can cause severe erosion problems. This fact is undesirable to urbanization due to the risk of accidents such as landslides and erosion (Pissarra et al., 2004).

Finally, to a lesser extent, there was the existence of areas of Gleysols (haplic eutrophic $\mathrm{HGPe}$ ), hydromorphic soils that occur in regions with lower and humid terrains, at about $8.12 \%$ of the area. According to EMBRAPA (2006), Gleysols are hydromorphic lowlands that usually occupy landscape depressions, subject to flooding, present over the plains of the rivers, and in the valley bottoms where water tables surface. They occur in flat reliefs, which entail the accumulation of water throughout the year, or much of it. The relative and absolute values are shown in Table 1.

Table 1 - Soil classes in the watershed of the Samambaia creek. Soil types in the Samambaia's watershed.

\begin{tabular}{lcc}
\hline Soil & Area (ha) & $\%$ \\
\hline Latosol & 2257.32 & 65.18 \\
Argisol & 924.28 & 26.69 \\
Gleysol & 281.23 & 8.12 \\
\hline
\end{tabular}

The watershed of Samambaia creek has an altimetric range of $171 \mathrm{~m}$ (Figure 1A). Near the source of this creek, in the North, there was an altitude of 872 $\mathrm{m}$, near the mouth (Meia Ponte River). The value recorded for altitude was $701 \mathrm{~m}$ (Figure 1B).

The historical survey showed that the natural vegetation consisted of clean and dirty fields, "cerrado" and gallery forests, part of the Cerrado biome (Figure 1C). However, currently, due to the urbanization, part of this natural vegetation was destroyed, replaced mostly by agricultural activities and urban settlements. In the field, it was found that in the northern portion of the watershed there is a predominance of activities related to livestock, while in the southern portion there is a predominance of urban areas (Figure 1D). There was a removal of vegetation between the years 1986 and 2011, when 669.42 ha $(43.88 \%)$ of vegetation that existed in 1986 gave way to pastures and urban areas. Of the $44.05 \%$ of existing forests in 1986 (Figure 2A), in 2011 (Figure 2B) there were only $24.72 \%$ remaining. On the other hand, the amount of urban areas increased significantly from $0.81 \%$ in 1986 to $20 \%$ in 2011 , an increase of 664.43 ha. 
(A)

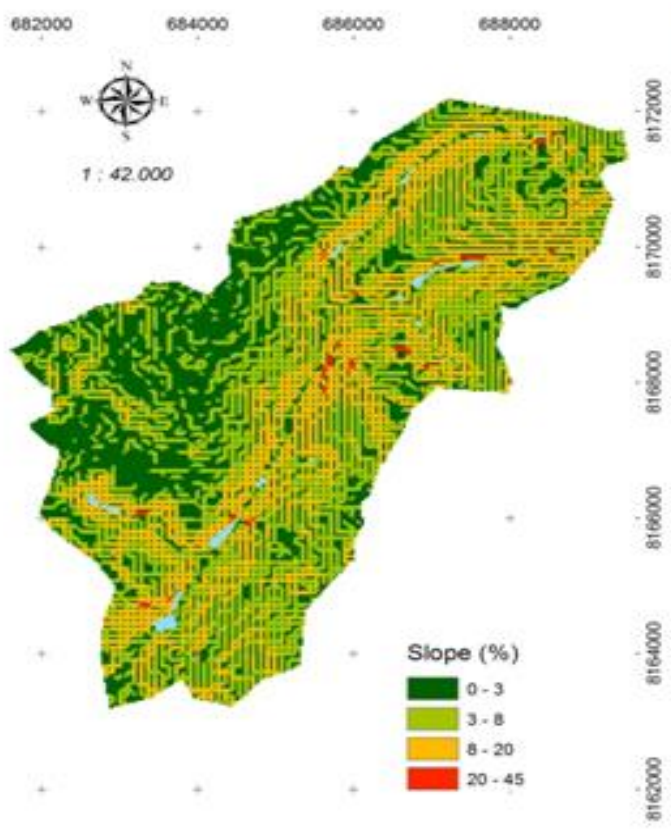

(C)

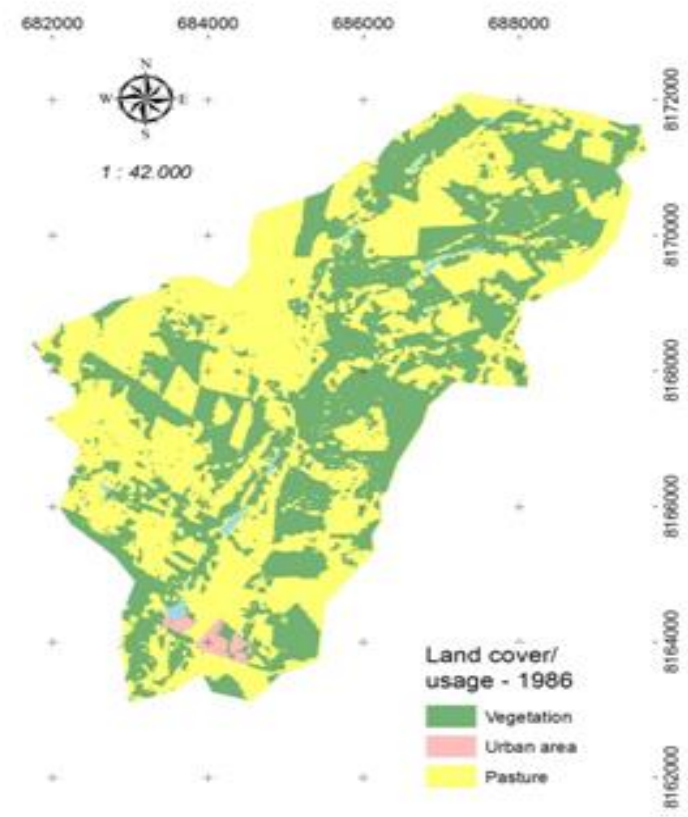

(B)

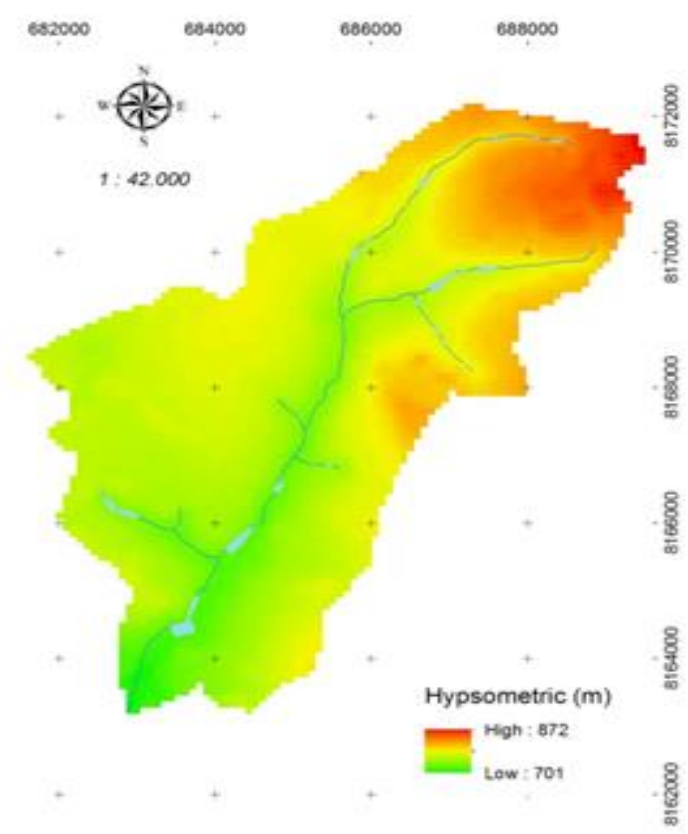

(D)

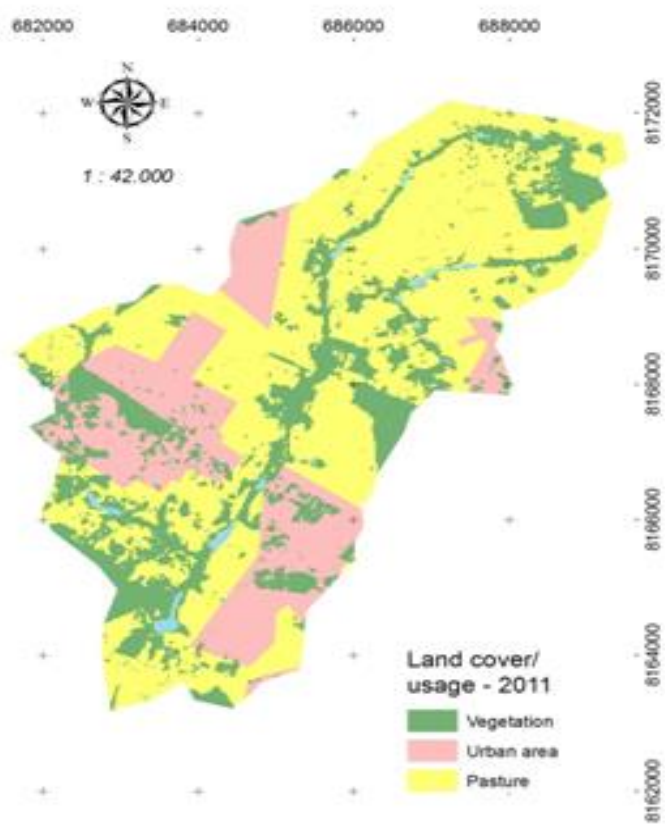

Figure 1 - (A) Slope map, (B) Hypsometric distribution, (C) Land use map in 1986, (D) Land use map in 2011.
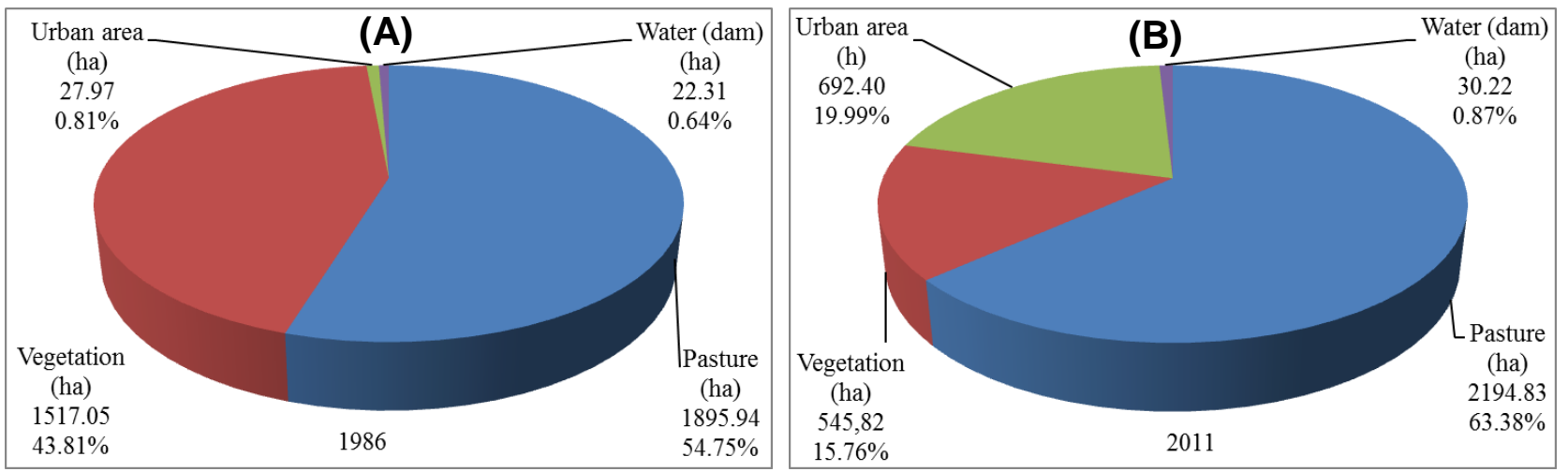

Figure 2 - Use and occupation proportion of land in the years (A) 1986 and (B) 2011. 
Table 2 shows the data on morpho physiographic characterization of Samambaia creek's watershed, allowing the analysis of watershed behavior as to risks of flooding, mainly due to urbanization.

Table 2 - Morpho physiographic characteristics of Samambaia creek's watershed.

\begin{tabular}{lc}
\hline Morpho physiography & Valor \\
\hline Drainage area (A) & $34.63 \mathrm{~km}^{2}$ \\
Perimeter (P) & $29.65 \mathrm{~km}$ \\
Coefficient of Compactness (Kc) & $1.41^{*}$ \\
Form Factor (F) & $0.30^{*}$ \\
Circularity Index & $0.50^{*}$ \\
Maximum slope & $28.33 \%$ \\
Medium slope & $5.12 \%$ \\
Minimum slope & $0 \%$ \\
Maximum Height & $872 \mathrm{~m}$ \\
Minimum Height & $701 \mathrm{~m}$ \\
Watershed order (STRAHLER, 1957) & $2^{*}$ \\
Drainage density & $0.58 \mathrm{~km} \mathrm{~km}-2$ \\
Sinuosity index (Is) & $1.19^{*}$ \\
Length of main riverbody & $12 \mathrm{~km}$ \\
Length of all canals (Lt) & $20.01 \mathrm{~km}$ \\
\hline
\end{tabular}

The watershed of Samambaia creek has a high diversity of forms of occupation and land use. They are found in agricultural, urban, leisure areas, housing developments and pasture areas. In this study, it was possible to quantify an increase of 664.43 ha in urban areas, representing an increase of $19 \%$, with the suppression of native vegetation. According to Christofoletti (1969), drainage densities values smaller than $7.5 \mathrm{~km} \mathrm{~km}^{-2}$ are considered as low drainage density; values between 7.5 and $10 \mathrm{~km} \mathrm{~km}^{-2}$, an average drainage network density; and higher than $10 \mathrm{~km} \mathrm{~km}^{-2}$, a high density of drainage network. Santos \& Moraes (2012) found a slope value of $1.658 \mathrm{~km} \mathrm{~km}^{-2}$ in their study, featuring little volume of river flow, and low land drainage.

In this case, the watershed of the Samamabaia creek has a drainage network density with a low propensity to flooding. This is mainly because much of the area $(\approx 75 \%)$ has a maximum slope of $8 \%$ (Figure $3 \mathrm{~A}$ ), with a predominance of Latosol. However, while presenting characteristics that favor good water infiltration into the soil, this area can generate waterproofing problems caused by urbanization.

The form factor and the circularity index, respectively 0.3 and 0.5 , characterize the watershed with a tendency to a rectangular format, and not a circular one. It denotes a greater concentration time and greater water infiltration along the watershed (Olszevski et al., 2011), reinforcing the low propensity to flood.
According to Villela \& Matos (1975), sinuosity indexes close to the unity indicate that the canals tend to be straight. Values higher than two indicate that the canals tend to be tortuous. Intermediate values denote transitional forms, regular and irregular. Thus, the Samambaia creek has a riverbed with a rectilinear tendency, i.e., an index of 1.19. According to Antoneli \& Thomaz (2007), this type of riverbed encourages greater sediment transport, avoiding accumulations on its banks, which would prevent flooding in areas near the bed and which is reinforced by the higher slope located near drainage networks (8-20\%).

\section{Conclusions}

The morphometric and physiographic characteristics of Samambaia creek's watershed show a low propensity to floods, also featuring an intense urbanization over the last 25 years, with an increase of approximately $20 \%$.

\section{References}

Antoneli V, Thomaz EL (2007) Caracterização do meio físico da bacia do Arroio Boa Vista, Guamiranga, PR. Revista Caminhos da Geografia 8(21):46-58.

Cardoso CA, Dias HCT, Soares CPB, Martins SV (2006) Caracterização morfométrica da bacia hidrográfica do rio Debossan, Nova Friburgo, RJ. Revista Árvore 30(2):241-248.

Carelli L, Lopes PP (2011) Caracterização fisiográfica da bacia olhos d'água em feira de Santana/BA: Geoprocessamento aplicado à análise ambiental. Boletim Goiano de Geografia 31(2):43-54.

Carvalho FMV, Ferreira LG, Filho JAFD, Bini LM (2008) Padrões de autocorrelação espacial de índices de vegetação MODIS no bioma cerrado. Revista Árvore 32(2):279-290.

Christofoletti A (1969) Análise morfométrica de bacias hidrográficas. Notícia Geomorfológica 18(9):35-64.

Colombo R, Vogt JV, Soille P, Paracchini, ML, Jager A (2007) Deriving river networks and catchments at the European scale from medium resolution digital elevation data. Catena 70(3):296-305.

EMBRAPA - Empresa Brasileira de Pesquisa Agropecuária (2006). Centro Nacional e Pesquisa em Solos. Sistema brasileiro de classificação de solos, Brasília. 306p.

ESRI - Environmental Systems Research Institute (2008) ArcGIS 9.3. Redlands. California, Software. 
IBGE - Instituto Brasileiro de Geografia e Estatística (2011) Ministério do Planejamento, Orçamento e Gestão. Disponível em: <www.ibge.com.br>. Acesso em: 02 de Agosto de 2013.

Latrubesse EM, Stevaux JC, Sinha R (2005) Tropical Rivers. Geomorphology 70(3-4):187-206.

Lima JEFW, Silva CL da, Oliveira CA da S (2001) Comparação da evapotranspiração real simulada e observada em uma bacia hidrográfica em condições naturais de cerrado. Revista Brasileira de Engenharia Agrícola e Ambiental 5(1):33-41.

Lucas AAT, Folegatti MV, Duarte SN (2010) Qualidade da água em uma microbacia hidrográfica do Rio Piracicaba (SP). Revista Brasileira de Engenharia Agrícola e Ambiental 14(9):937-943.

Olszevski N, Fernandes Filho El, Costa LM, Schaefer CEGR, Souza E, Costa ODV (2011) Morfologia e aspectos hidrológicos da bacia hidrográfica do rio Preto, divisa dos estados do Rio de Janeiro e de Minas Gerais. Revista Árvore 35(3):485-492.

Pissarra TCT, Politano W, Ferraudo AS (2004) Avaliação de características morfométricas na relação solo-superfície da Bacia Hidrográfica do Córrego Rico, Jaboticabal (SP). Revista Brasileira de Ciência do Solo 28(2):297-305.
Santos DAR, Moraes F (2012) Análise morfométrica da bacia hidrográfica do rio lago verde como subsídio à compartimentação do relevo da região de lagoa da Confusão (TO). Revista Geonorte 3(4):617-629.

Sordi MV, Vargas KB, Santo TD, Nascimento PB (2012) Caracterização fisiográfica da bacia hidrográfica do Ribeirão laçador, Faxinal (PR). Revista Geonorte, 2(4):289-300.

Strahler AN (1957) Quantitative analysis of watershed geomorphology. Transactions of the American Geophysical Union 38(6):913-920.

Teodoro VLI, Teixeira D, Costa DJL, Fuller BB (2007) O conceito de bacia hidrográfica e a importância da caracterização morfométrica para o entendimento da dinâmica ambiental local. Revista Uniara 11(11):137-156.

Vanacker V, Molina A, Govers G, Poesen J, Dercon G, Edeckers S (2005) River canal response to shortterm human-induced change in landscape connectivity in Andean ecosystems. Geomorphology 72(1-4):340-353.

Villela SM, Matos A (1975) Hidrologia aplicada, McGraw-Hill do Brasil. 245 p. 